\title{
PROLEGOMENA TO ANY FUTURE HISTORICIZING: THE DILTHEY-HUSSERL DEBATE AND WHY IT MATTERS FOR CRITICAL PHENOMENOLOG Y
}

\author{
CHRISTOPHER R.MYERS \\ Fordham University
}

The question is, does history that has discovered its own meaning still have any meaning? And is it history anymore? - Václav Havel, "Stories and Totalitarianism"

For more than a century, phenomenology's relation to history has remained a problem for phenomenological analysis. This can in part be attributed to the circumstances surrounding the beginnings of phenomenology. As Europe moved increasingly toward world war at the turn of the 20th century, a growing consciousness of the historical relativity of all values and knowledge spread throughout the continent, leading Ernst Troeltsch to speak of the "crisis of historicism" (Rand 1964, 504-05). In this same context, Edmund Husserl framed phenomenological analysis in opposition to history. While Husserl (2002) recognized the "tremendous value" that history has to offer philosophical thinking, he believed that a purely historical reduction of consciousness necessarily results in the relativity of historical understanding itself, like a serpent that bites its own tail (280). If phenomenology was to be a genuine science, it had to attempt a phenomenological reduction which would seize upon the essence of our historical being, i.e., our essence as beings that exist within history and are inseparable from it. What was required over and beyond a historical understanding of lived experience was an analysis of the structure of historicity itself (293-94).

Since Husserl's representation of the relationship between phenomenology and history in 1911, phenomenologists have worked to re-problematize this relationship - and this includes the recent line of analysis which has taken the name "critical phenomenology." As Gail Weiss, Ann V. Murphy, and Gayle Salamon (2019) have suggested, critical phenomenology makes use of phenomenological description to analyze the ways that power relations structure our experience. Critical phenomenologists examine the sociohistorical conditions behind the perceptual patterns and affective dispositions of the body, as well as the conditions behind the phenomenological attitude itself. Now, insofar as critical phenomenology concerns itself with the socio-historical conditions of phenomenological 
analysis, it seems to turn back on Husserl's assessment of history, and moreover on his 1911 correspondence with Wilhelm Dilthey. While Husserl called for a phenomenology which would make intelligible the structure of historicity itself, it was Dilthey who suggested that understanding needed to be reconceived as a hermeneutic activity: an interpretive activity which turns back on itself and moves between lived experience and history.

The aim of this paper is to revisit Husserl and Dilthey's 1911 correspondence in order to develop a deeper perspective on this tendency in critical phenomenological research: the tendency to historicize lived experience. I argue for two theses. First, while both Husserl and Dilthey recognized that lived experience is always historically situated, they diverged in their approaches to the interpretation of historicity-Husserl adopting a transcendental approach, and Dilthey a hermeneutic approach. This divergence grew out of Husserl and Dilthey's solutions to the crisis of historicism, and it led them to adopt opposed views on the activity of historicizing. Second, while Husserl's treatment of historicity is in tension with critical phenomenology's commitment to historicizing the phenomenological attitude, Dilthey's treatment suggests that our historicity needs to be interpreted as something that is itself socially and historically conditioned. Dilthey's attempt to achieve a truly hermeneutic conception of understanding led him to represent historicizing as a source of radical possibility. Accordingly, his disagreement with Husserl offers insight for critical phenomenology's treatment of the relationship between phenomenology and history.

\section{DILTHEY AND THE CRISIS OF HISTORICISM}

In 1873, Wilhelm Dilthey observed that Europe was undergoing a "great crisis" as a consequence of the rise of historical consciousness (quoted in Ermarth 1978, 15). ${ }^{1}$ By "historical consciousness," Dilthey referred to the awareness that the whole of one's existence is a product of history. As historical science became increasingly prominent across Europe during the 19th century, human beings were made increasingly conscious of the historicity of all things, and were compelled to historicize every aspect of their nature: their reason, values, instincts, etc. Even knowledge itself had to be historicized, leading to the conclusion that our knowledge of history was itself something historically relative. All aspects of human life were suddenly in crisis - a situation Troeltsch would describe fifty years later as the "crisis of historicism" (Rand 1964, 504-05).

In contrast to Troeltsch - who saw no other way to counteract the crisis of historicism than by looking to the ahistorical - Dilthey believed the solution to this crisis must be sought

\footnotetext{
${ }^{1}$ Dilthey had made similar observations before this. As a student in the 1860's, Dilthey (1978) observed that "the problems of philosophy, history, and politics are now mutually intertwined" (15).
} 
in historical consciousness itself. ${ }^{2}$ This is seen in his description of "the problem posed by this epoch":

[E]verything historical is relative in the sense that if we gather it all in consciousness, it seems to surreptitiously breed dissolution, skepticism, and impotent subjectivity. This exposes the problem posed by this epoch. What is relative must be brought into a more fundamental connection with what is universally valid . . . Surely, historical consciousness itself must contain the rules and the power for dedicating ourselves freely and with sovereignty, in the fact of the past, to a unified goal of human culture. (Dilthey 2019, 158-59)

What is distinct about Dilthey's response to the crisis of historicism is that he did not believe we could turn to an ahistorical system of thinking such as positivism or metaphysics. For Dilthey the way forward was not attempting to transcend the historicity of human life, but rather, attempting to examine the nature of historical consciousness. Such an attempt would resemble the Kantian project in its determination of the essential limitations of historical consciousness, but with a major difference: "Kant's a priori is fixed and dead; but the real conditions of consciousness and its presuppositions, as I grasp them, constitute a living historical process, a development" (Dilthey 1989, 500-01). Dilthey names this project a "critique of historical reason": a critique of human beings' capacity to know themselves and their history from within history (165).

Dilthey believed his critique of historical reason would provide an epistemological foundation for future research in the human sciences (Geisteswissenschaften), i.e., future research which concerns human life, society, and history. Yet the task of this critique extended well beyond epistemology: what was in question for Dilthey was the philosophical character of living historically. ${ }^{3}$ In search of something "universally valid," Dilthey identifies the starting point for such a critique as a return to lived experience (Erlebnis): the pre-reflective reality in which "what is there for me" is solely the content of consciousness. In the "Breslau Draft," he asserts "the principle of phenomenality": the principle that "[e]verything is a fact of consciousness, and accordingly is subject to the conditions of consciousness" $(1989,247)$. Against any metaphysical belief in an external world or the unchanging identity of the subject behind experience, Dilthey argues that "knowledge may not posit a reality that is independent of lived experience" (202). Lived experience is both the starting point and context for all possible understanding, and this includes our understanding of the past.

Yet Dilthey complicates this principle by introducing a second principle: that the psychical nexus which encompasses the facts of consciousness must be recognized as contained "in the totality of psychic life" (263-64). For Dilthey, to speak of lived experience

\footnotetext{
2 Troeltsch (1964) attempts to counteract the crisis of historicism by turning to an ahistorical Neo-Platonism (48ff.).

${ }^{3}$ In his correspondence with Dilthey in 1895, Count Yorck von Wartenburg suggests that Dilthey refer to the character of being historical as "historicity." While Heidegger reads into this correspondence that it was Count Yorck von Wartenburg who recognized the true difference between the "ontical" and the "Historical," it should be emphasized that Count Yorck was attempting to designate what he saw in Dilthey's own project (Dilthey \& v. Wartenburg 2020, 185-86).
} 
as something singular is an "abstraction": lived experience exists within the movement of time, and therefore is what it is because it is a part of psychic life understood as an interconnected temporal whole (67). Lived experience is always situated within the fullness of social and historical life, and correspondingly acquires its meaning from the context of our relationships with others, our socio-cultural context, and history itself $(1989,279$ 84). Notice how this second principle completely transforms what Dilthey means by phenomenality (i.e., the notion that everything is a fact of consciousness) and moreover prefigures the recent emphasis made by critical phenomenologists on the socio-historical conditions of experience. While it remains the case that "what is there for me" exists solely in lived experience, it is nevertheless the case that lived experience is itself an abstraction insofar as it exists within the movement of time. Lived experience and history are related to one another as part and whole within the interconnected nexus of life itself - what Dilthey calls the life-nexus (Lebenszusammenhang). ${ }^{4}$

Dilthey's solution to the crisis of historicism is seen in his attempt to fundamentally reconceive of Verstehen (understanding). In multiple works, Dilthey identifies the foundation of the human sciences as descriptive psychology: the study of the connectedness of psychic life. This appeal to descriptive psychology has been a source of extreme confusion amongst Dilthey's readers. While some have criticized Dilthey for trying to replace empirical psychology with an introspective "armchair psychology," what Dilthey (2010) actually means by descriptive psychology is not an analysis of psychic life as an introspective reality, but rather psychic life as the context of understanding. ${ }^{5}$ He writes:

Life is the basic fact that must form the starting point of philosophy. Life is that with which we are acquainted from within and behind which we cannot go. ... . Life is historical to the degree that it is apprehended as advancing in time and as an emerging productive nexus. Life as history is possible because this process is re-created in memory, not as the production of its particulars, but as the recreation of the nexus itself and its stages. . . . That is history. (280)

For Dilthey, descriptive psychology refers to the study of psychic life understood as "an emerging productive nexus": a nexus in which lived experience and history are related to one another as part and whole. In contrast to empirical psychology, which accepts as its starting point a distinction between subject and object, descriptive psychology analyzes life itself as the context within which lived experience emerges, and thus as a context that is intersubjective and historical from the beginning. In this way, Dilthey's descriptive psychology is founded upon a fundamental reevaluation of what understanding is - a reevaluation which recognizes that the "object" of understanding is the context of understanding itself. For Dilthey, understanding needs to be reconceived as a hermeneutic activity: an activity in which we continually turn back on the conditions of our own understanding and move between lived experience and history. While lived experience needs to be interpreted on the

\footnotetext{
${ }^{4}$ In addition to Dilthey's description of the life-nexus in his "Breslau Draft," see (1977, 35; 2010, 214-18).

${ }^{5}$ In particular, this criticism is made by Ebbinghaus (De Mul 2014, 187-89).
} 
basis of our understanding of our historical situatedness, history needs to be interpreted on the basis of what is given in lived experience. ${ }^{6}$

For our purposes, what is most important to emphasize in Dilthey's reevaluation of understanding is that the activity of historicizing becomes a source of radical possibility. In Formation of the Historical World in the Human Sciences, Dilthey (2010) describes understanding as the activity of interpreting what is given to us in experience (e.g., the expressions of others, works of art, political movements, etc.) as "objectifications" of life itself (103-05). ${ }^{7}$ Using Hegel's concept of objective spirit, Dilthey suggests that everything in the world is an objectification of life insofar as it is always already connected to us as parts of the same life-nexus. What seems to exist "outside" of us is in fact related to us within "the inner reality of life," and therefore provides the material for an understanding of the life-nexus. Dilthey describes the activity of interpreting this material as a process of "gradual elucidation":

Lived experiences ... seem to only give us knowledge of something singular ... [yet] understanding overcomes this limitation of the individual lived experience . . . Understanding presupposes experience, but lived experience only becomes life-experience if understanding leads us from the narrowness and subjectivity of experiencing into the region of the whole and the general. . . . The basic relationship between lived experience and understanding is [therefore] that of mutual dependence. . . . Understanding constantly widens the range of historical knowledge . . . [while] at the same time the extension of the historical horizon makes possible the formation of ever more general and fruitful concepts. (162-7)

For Dilthey, understanding presents the possibility of experiencing beyond the narrowness of our own lived experience. By utilizing what is given in experience to acquire a sense for history, we become able to re-interpret our own experience on the basis of the lived realities of others, of society, and of history. The relationship between understanding and lived experience remains one of mutual dependence, however, insofar as our conception of history is continually re-opened by what is given to us in experience. What emerges in lived experience will change our understanding of the way things have been in the past, and thus the meaning that is contained in historical life is for Dilthey necessarily something open and indefinite. ${ }^{8}$

\footnotetext{
${ }^{6}$ Dilthey insists that such an activity must be interdisciplinary, moreover, insofar as it is only through the collective effort of the human sciences that we grasp the fullness of our hermeneutic situation.

${ }^{7}$ Amongst things that are given in the socio-historical world, Dilthey (1989) makes a distinction between systems of culture and external organizations (94). A system of culture is a "complex of purposes" that is formed when various individuals become related to one another through shared purposes (e.g., religion, law, and art). An external organization of society is an association of wills that is formed when individual wills unite to form a single whole: a community, a framework, a "state."

8 While Dilthey (1989) recognizes that continual re-interpretation brings us closer to the meaning of historicity, he insists that a complete scientific account is not possible (440).
} 
Insofar as Dilthey (2010) believed the activity of historicizing enables us to experience lived realities beyond the narrowness of our own experience, he represented historicizing as a source of radical possibility: "[h] uman beings bound and limited by the reality of life are liberated not only by art . . . but also by the understanding of the historical" (237). Yet Dilthey also went a step further than this: he suggested that we are able to experience not merely lived realities beyond our own, but lived realities of the past precisely as they were (i.e., "re-experiencing"). This claim has been widely criticized by 20th century hermeneutic thinkers like Martin Heidegger and Hans-Georg Gadamer: it assumes the past is fixed in some way, and thereby contradicts Dilthey's suggestion that the meaning of the historical nexus is open and indefinite. This claim points toward a larger problem, moreover: the tension between Dilthey's commitment to the possibility of universally valid understanding and his commitment to the historicity of all understanding (Bambach 2019, 92). Although Dilthey (1960) reconceives of understanding as a hermeneutic activity, he maintained that a genuine understanding of lived experience would need to be one that remains valid outside of our historical circumstances (233).

This tension between Dilthey's belief in the historicity of all understanding and the possibility of universally valid understanding will be discussed further below. For now, we should emphasize the genuine insight behind Dilthey's solution to the crisis of historicism. While the skeptic is ready to dismiss the possibility of understanding by appealing to our historical situatedness, Dilthey suggests that our historical situatedness is precisely what makes understanding possible. It is because we are historically situated that we have access to the life-nexus: all that we experience helps us acquire an understanding of the greater whole of historical development, and our understanding of history in turn helps us acquire a better understanding of lived experience. The immediate consequence of Dilthey's solution to the crisis of historicism is therefore that our historical situatedness becomes essential for the possibility of understanding, and that the activity of understanding itself becomes a source of possibility. By learning to historicize ourselves and our lived experience, we are able to recognize both the narrowness of our experience and the possibility of experiencing otherwise.

\section{HUSSERL AND THE CRISIS OF HISTORICISM}

Like Dilthey, Husserl (2001) believed that the phenomenality of experience is the only genuine starting point for understanding. In the Logical Investigations, Husserl represents phenomenology as the description of lived experience: a self-reflective analysis in which we turn our focus from the "naïve" positing of independently existing objects to the essence of conscious experience itself (96-97). For Husserl, consciousness is always consciousness of something. It is intentional in the sense that it is always directed at some content. This implies the possibility of phenomenology as a science of intentionality, i.e., a science of the essence of what is intended in consciousness as well as the way in which is intended (127-28). What is required is a reflective turn toward the meaning of what we are conscious of - or as he 
frames it in Ideas I, a "phenomenological epoché": a bracketing of the "natural attitude" and an analysis of the world as it is given (1983, 65-66).

When Dilthey (2010) read Husserl's Logical Investigations he described it as "epoch-making" and compared it to his own descriptive psychology $(30,34) \cdot{ }^{9}$ He began a correspondence with Husserl in 1905, and soon after Husserl (1977) would also recognize a kinship between Dilthey's descriptive psychology and phenomenology (25). Yet where Dilthey and Husserl remained at odds with one another was in their solutions to the crisis of historicism. This became clear with Husserl's publication of "Philosophy as a Rigorous Science" in 1911: a text that marks the first indication of what I propose we call the "Dilthey-Husserl debate." 10

In this article Husserl argues that phenomenology is the sole means by which philosophy can become genuinely scientific, and he does this by criticizing two alternatives: naturalistic philosophy and world-view philosophy (2002, 253). By "world-view philosophy," Husserl designates a kind of philosophy which he considers a "child of historicistic skepticism": a philosophy which suggests that all sciences and philosophies are derived from the worldview of their age, and that all world-views are themselves teleologically linked in the course of history (283-86). Husserl's reference to "world-view philosophy" here is significant in that Dilthey had published an article earlier that year titled, "The Types of World-View and their Development in Metaphysical Systems." Dilthey suggests in this article that a select few world-views have served as background understandings for societies' interpretations of the meaning and sense of world, and - contra historical relativism - these world-views have their legitimacy in the fact that they are rooted in the overall structure of the life-nexus (Dilthey 2019, 258-62). While Dilthey meant for his account of world-views to propose an alternative to skepticism, Husserl evidently did not accept this conclusion. In "Philosophy as a Rigorous Science" he identifies "world-view philosophy" as the sole form of philosophy that is left after one has accepted historical relativism, and he moves to criticize it.

What is interesting is where Husserl does - and does not - include Dilthey within his discussion. As soon he turns to the crisis of historicism, Husserl makes use of several passages from Dilthey. ${ }^{11} \mathrm{He}$ observes with Dilthey that the rise of historical consciousness has made people lose faith in their age's values and ways of life, and he further observes that the logic of historicism can be used to relativize any science which pursues objective validity. Husserl (2002) concludes: "when historicism is consistently carried through to its conclusion, one ends up with extreme skeptical subjectivism" (280).

\footnotetext{
${ }^{9}$ In the following years, Dilthey would become the first prominent German philosopher to use Husserl's work in his own courses, and would even begin using the term "phenomenology" alongside "descriptive psychology" in his unpublished writings (Ermarth 1978, 197, 204).

${ }^{10}$ I have chosen to speak of the "Dilthey-Husserl debate" only to emphasize the significant divergence between these thinkers on the question of our concern: the limits of historicizing and the nature of historicity. Dilthey and Husserl themselves never engaged in an actual debate or public disagreement. In fact (as I hope I have made clear), Dilthey and Husserl shared much in common, and greatly admired one another's work.

11 Specifically, Husserl (2002) makes use of passages from "The Types of World-View and Their Development in Metaphysical Systems" (279-80).
} 
From this point Husserl asserts the need to bracket the fact of our historical situatedness, and he questions whether historical facts should have any pertinence to understanding whatsoever. He writes:

The foregoing should suffice to gain the concession thathowever great are the difficulties that the relationship between what obtains in the flux and objective validity . . may pose to the clarifying understanding - the distinction and opposition must be acknowledged. (280-81)

Husserl insists upon an opposition between historical facts and objectively valid understanding, and implies that the threat of skepticism is ultimately a decisive argument against historical consciousness itself. If our awareness of the historicity of all things conflicts with the possibility of genuine understanding, then this awareness needs to be abstracted from altogether: we should pursue objective validity over against historical facts. Husserl goes on to conclude that we should set our sights on a philosophical science that does not "get bogged down in the historical" (293-94). Where "historical-critical activity" takes into consideration only what has factually existed, a genuine philosophical science would be one which carries out "the phenomenological seizing upon essences": a seizing of the ideal content or "essence" of what is experienced in time. This alone can constitute the foundation of a rigorous science: knowledge of what is "pure" (272-75).

It is telling that Dilthey's name drops out of Husserl's discussion the moment he begins to argue that we should abstract from what is historical. Despite the fact that Dilthey's critique of historical reason is concerned precisely with reconceiving of understanding in the awareness that we cannot transcend our historical situatedness, Husserl omits Dilthey's project from his focus at precisely this moment. Dilthey is considered merely in a brief footnote:

Dilthey likewise rejects historicistic skepticism; but I fail to understand how he can believe he has obtained from his very instructive analysis of the structure and typology of world-views decisive reasons against skepticism. For as is argued above in the text, a human science (which is, after all, empirical) can argue neither against nor for anything that lays claim to objective validity. (2002, $281 \mathrm{n} .13)$

Husserl is right that there is a conflict between Dilthey's commitment to the possibility of objectively valid understanding and his emphasis on the historical situatedness of understanding. If we continue to demand that understanding remain valid outside of our own circumstances, we will be vulnerable to the criticism of the skeptic. Yet Husserl's criticism of Dilthey goes one step further than this: he implies that skepticism could only be rejected with a complete bracketing of the historicity of understanding. Husserl asserts that what is required over and beyond the historicizing of consciousness is a phenomenological seizing of the essence of historicity itself, and thus a philosophical science which abstracts from its own historicity in order to approach it as an object of analysis. 
Husserl's footnote points to a central divergence between Dilthey and Husserl: a divergence concerning the interpretation of historicity. While Dilthey's conception of understanding allows him to suggest that any interpretation we might have of our historical situatedness is itself something historically situated - and therefore something that remains to be re-interpreted by way of reference to the lived realities of others-Husserl's conception of understanding requires that we bracket our historical situatedness and analyze it as if we were looking from "above." For Husserl, any "understanding" of our historical situation that is itself attributable to the particulars of our historical situation is not an understanding at all - it is not a seizing of the essence of historicity itself. This divergence can be seen even more clearly in Dilthey and Husserl's correspondence after the publication of "Philosophy as a Rigorous Science." After reading the article, Dilthey wrote to Husserl and rejected Husserl's characterization of his work as historicist (Biemel 1968, 434-36). Dilthey asserts that Husserl fails to show that a "systematic investigation based on history" is tantamount to either historicism or skepticism: he passes over the possibility that understanding might be reconceived in such a way that embraces the situatedness of lived experience. In his reply to Dilthey, Husserl denies that any of his arguments were directed against Dilthey (438). He explains that he did not mean to include Dilthey in his attack on skepticism, and that he intends to publish a clarificatory note in order to prevent further misinterpretations. ${ }^{12}$

Husserl's response to Dilthey makes no mention of the footnote in which he suggests that Dilthey failed to overcome skepticism. It is a surprising omission, and it makes us wonder: given that Dilthey conceived of understanding as inseparably linked to the activity of historicizing, how could Husserl have recognized Dilthey's philosophical project as anything but skepticism? In this 1911 correspondence Dilthey and Husserl simply cannot help but speak past one another - and the reason for this lies in the essential difference between their approaches to the interpretation of historicity: (1) Dilthey a hermeneutic treatment of historicity, and (2) Husserl a transcendental treatment of historicity. By making this distinction, my intention is not to imply that Dilthey's thought is lacking in any kind of transcendentalism, or that Husserlian phenomenology is transcendentalism at its core. ${ }^{13}$ Instead, this distinction concerns solely the divergence between Dilthey and Husserl's approaches to the question, how can we understand our historical situatedness in such a way that does not lead to skepticism? For Dilthey, the answer lies in a radical concept of historicizing. We use what is given to us in experience to interpret our historical circumstances, we use this interpretation to clarify the meaning of our lived experience, and then we turn again to what is given to us in experience to re-interpret our historical circumstances. This is a distinctively hermeneutic treatment: the interpretation of our historical situatedness is potentially endless insofar as our sense for history is recognized as historically situated itself. For Husserl, on the other hand, the answer lies in the task of understanding our

12 At one point, Husserl even writes: "it really seems to me that there are no serious differences between us. I believe that a long conversation would lead to full understanding" (438, my translation).

13 As I will discuss, Dilthey's project is often read as containing transcendental elements. See: Ermarth (1978, 355-57) and De Mul (2014, 158-59). 
historical situatedness in such a way that is not historically situated. This is a distinctively transcendental treatment: we pursue the possibility of an understanding that lies beyond the limits of historicizing - an understanding of historical situatedness itself. In characterizing Husserl's approach as transcendental, note that even the insistence that our understanding of historicity is achieved in historically specific circumstances is not enough to negate its transcendental character. ${ }^{14}$ It remains the case that we are determined not to "get bogged down in the historical": our understanding of historicity will not be an understanding at all if it exhibits any kind of historically-situated standpoint. Where but to a transcendental standpoint could we be headed?

Some scholars have suggested that Husserl better distinguishes his treatment of historicity from transcendentalism after Dilthey's death in the fall of $1911 .{ }^{15}$ After all, Husserl was always aware that consciousness is factually situated in historical circumstances. As Husserl writes to Georg Misch in 1930:

[I want to] make plain that the 'ahistorical Husserl' had to have at times distanced himself from history (which he nevertheless had constantly had in view) precisely in order to come so far in method as to pose scientific questions in regard to it. (Husserl, quoted in Scharff 2018, 38)

Following Heidegger's (2008) Being and Time, Husserl insists to Misch that his phenomenological method never sought to abandon history altogether - the goal was instead to examine history as an object for phenomenological analysis. Yet as Robert C. Scharff (2018) has rightly observed, Husserl continues to approach the historicity of consciousness in this statement as an object of analysis (something "in view") rather than the context within which we analyze (38). We still see the same difference: while Dilthey approaches our historicity as a context that can never be brought entirely into view, Husserl indicates that our historicity can be understood in such a way that our understanding of it does not lead back to our historical situatedness.

This is seen equally in Husserl's Crisis of the European Sciences and Transcendental Phenomenology (1970). From the beginning of the Crisis Husserl is concerned with the historicity of phenomenological analysis, and this concern leads him to the concept of the life-world (Lebenswelt). Husserl (1970) observes that all philosophical thinking and scientific inquiry emerges in the context of the "life-world": the pre-given background of senses and meanings that is there for us in everyday experience (70-73, 124-25). The life-world is the "horizon" within which we live, acquire values, and interact with others. While previous philosophers

14 For instance, Husserl recognizes "the tremendous value of history in the broadest sense for the philosopher." Yet he moves from this recognition to immediately assert that phenomenology must take a philosophical perspective on the historical field (Husserl 2002, 283).

${ }^{15}$ For instance, see Johnson 1980, 78. 
have sought to achieve objective a priori knowledge, Husserl insists that any such knowledge is necessarily posited on the basis of "the life-world a priori" and the pre-given horizon of meaning within which we pursue knowledge (103-11). Accordingly, metaphysical accounts are always founded on a suppression of the life-world - and phenomenology, insofar as it concerns itself with the historicity of experience, is tasked with a complete change in orientation: a change in which the life-world itself is made the object of a "universal epoché" (148-51).

Husserl's concept of the life-world shares important similarities with Dilthey's concept of the life-nexus. ${ }^{16}$ Both concepts serve as reminders that the sciences are rooted in prereflective experience. Both concepts are offered as a critique of metaphysics. Most relevant for our purposes, both concepts assert the essential historicity of consciousness and understanding. Yet in spite of these similarities, Husserl's attempt in the Crisis to bracket and analyze the life-world falls back into his earlier treatment of historicity. While the lifeworld is the horizon within which we carry out the phenomenological reduction, it is also something we are able to bracket as an object of analysis. Husserl (1970) writes:

But can we be content with this? Can we be satisfied simply with the notion that human beings are subjects for the world and at the same time are objects in this world? ... The epoché, in giving us the attitude above the subject-object correlation which belongs to the world and thus the attitude of focus upon the transcendental subject-object correlation, leads us to recognize, in self-recognition, that the world that exists for us, that is, our world in its being and being-such, takes its ontic meaning entirely from our intentional life through a priori types of accomplishments that can be exhibited rather than argumentatively constructed or conceived through mythical thinking. (180-81)

Contrary to the suggestion that Husserl's Crisis marks a significant departure from his early work, we can see that Husserl approaches historicity in much the same way. ${ }^{17}$ While the life-world is the historically-situated context in which we attempt a change in orientation, the change in orientation which characterizes the phenomenological epoché allows us to bracket the life-world itself as an object and analyze it as though we are "above" it. The possibility of understanding historicity itself is retained, even with the recognition that the life-world is the context within which we understand.

Husserl's treatment of historicity is seen even more clearly in his appendix to the Crisis, the "Origin of Geometry." Husserl (1989) insists that any historical fact necessarily presupposes "the universal a priori of history" insofar as the facts of history are rooted in the structure of what is generally human: the "unity of traditionalization" that underlies all past life-worlds (174). Husserl is careful to note that this unity is undetermined, and that the structure of historicity is open in its forward movement (173). Yet Husserl's reduction of historicity to the essential structure of "universal historicity" nevertheless frames

\footnotetext{
16 See Makkreel (1982, 40, 44).

17 See Carr (1974); Noé (1992); Johnson (1980).
} 
phenomenological analysis in opposition to a historicizing interpretation. For Husserl, the phenomenological epoché achieves something over and beyond historicizing.

\section{WHY THE DILTHEY-HUSSERL DEBATE MATTERS FOR CRITICAL PHENOMENOLOGY}

The relevance of the Dilthey-Husserl debate for critical phenomenology can be seen by focusing on a single tendency in critical phenomenological research: the tendency to historicize lived experience. As Weiss, Murphy, and Salamon (2020) have suggested, critical phenomenology refers to a line of critical analysis which "mobilizes phenomenological description in the service of a reflexive inquiry into how power relations structure experience as well as our ability to analyze that experience" (xiv). The "reflexive inquiry" that is particular to critical phenomenology involves an attention to "the multiple ways in which power moves through our bodies and our lives": how power relations structure the ways we see (i.e., perceptual patterns), the ways we feel (i.e., our affective state), etc. Now as Salamon emphasizes, this reflexive inquiry is in large part consistent with classical phenomenology: we find in Husserl and Merleau-Ponty a similar emphasis on the fact that experience is always situated within multiple horizons of significance (including social and historical horizons). Yet critical phenomenology extends the concerns of classical phenomenology by reflecting on the socio-historical structural conditions of its own emergence (Salamon 2018, 12). Lisa Guenther (2020) distinguishes critical phenomenology's focus from that of classical phenomenology as follows:

[Classical phenomenology] lights up the transcendental structures that we rely upon to make sense of things but which we routinely fail to acknowledge. In other words, phenomenology points us in a critical direction. But where classical phenomenology remains insufficiently critical is in failing to give a rigorous account of how contingent historical and social structures also shape our experience, not merely empirically ... . but in a quasi-transcendental way . . . Structures like "patriarchy," "white supremacy," and "heteronormativity" permeate, organize, and reproduce the natural attitude in ways that go beyond any particular object of thought. These are not things to be seen but rather "ways of seeing". . . We overlook them at our peril, even if our project is transcendental, because they are part of what we must bracket to get into the phenomenological attitude. (11-12)

Guenther suggests that critical phenomenology distinguishes itself from classical phenomenology through its concern with the contingent socio-historical structures that shape our experience. Much like transcendental structures, "whiteness" and "heteronormativity" are not given to us in lived experience - they are conditions of experience, or "ways of seeing." Yet while classical phenomenology might acknowledge "whiteness" and "heteronormativity" as life-world concerns, its focus on the transcendental 
structures of experience leads to the complete bracketing of these structures. Classical phenomenology fails to reckon with the reality that these "quasi-transcendental" structures continue to structure the phenomenological attitude itself - thus suggesting the need for an analysis which moves further in a critical direction. Critical phenomenology attempts this analysis by asserting that phenomenological description is itself conditioned by power relations, and that the phenomenologist needs to turn back and interrogate the conditions of the phenomenological attitude itself. The critical phenomenologist works to extend phenomenological description to objects of social and political critique-e.g., violence, racial injustice, gender inequality, etc. - and thereby redirects the self-reflective character of phenomenology against itself.

We can see immediately the relevance of the Dilthey-Husserl debate for critical phenomenology. After all, Dilthey and Husserl's disagreement concerned the interpretation of historicity. Given that critical phenomenology asserts the need to turn back on the phenomenological attitude and interrogate its socio-historical conditions, critical phenomenology demonstrates a similar occupation with the reality of our historical situatedness. Along this line, Weiss and Andrew Cutrofello (2019) have emphasized the significance of critical phenomenology's use of histories by suggesting that critical phenomenology is committed "to looking backward and taking responsibility for the injustices that have been committed in the past" (348). In particular, Weiss and Cutrofello observe that critical phenomenology is concerned with silent histories: histories that have contributed to the constitution of our experience without ever becoming visible to us. The critical phenomenologist attempts to recover these silent histories in order to open us to a more critical perspective on the way we experience things, and in this way they chart a path toward criticism through the historicization of lived experience.

But what exactly is the critical phenomenologist doing when they historicize the ways we experience things? As we have seen, Dilthey and Husserl acknowledged that lived experience is always historically situated. Yet they diverged on the question of how we can understand our historical situatedness without falling back into skepticism. Dilthey and Husserl's different approaches led them to conceive of historicity in significantly different ways, and depending on the way in which critical phenomenology approaches the treatment of our historicity, its commitment to historicizing could be two very different things. So what is historicizing? - or what should historicizing be?

Given that Husserl attempts to bracket and analyze the structure of historicity itself, his treatment of historicity is in clear tension with the aims of critical phenomenology. Consider what Husserl's approach implies for the activity of historicizing. Insofar as historicity is conceived in this way, the activity of historicizing takes on a specific meaning: to historicize the way we experience things is to interpret our experience against the background of a life-world whose own meaning is tied to the overarching unity of history. Even with the specification that this unity is "open" or "undetermined" in its meaning, historicizing is made into the activity of relating what is given to structures which are more fundamental: the unity that is implied by the historicity our society, of our historical period, etc. As Rudolf A. Makkreel (1982) has suggested, Husserl's analysis of the historical world amounts to a kind of Abbau (deconstruction): a movement from "higher levels" of the life- 
world (i.e., what is given in lived experience) to increasingly "lower levels" which ground the higher levels (i.e., what is essential in universal historicity itself) (55). Such a deconstructive approach is rooted in the belief that we can bracket our historical situatedness: we are able to deconstruct the structure of historicity precisely because we are able to speak and think about historicity without evidencing it.

But who decides what the structure of historicity consists in? Must not the determination of more "fundamental" levels of the life-world itself be historically situated and thus an object to historicize? In response to this question, David Carr (1974) has pointed out that "the whole idea of a historical reduction makes no sense except on the assumption of (an) ahistorical truth" (248). ${ }^{18}$ As soon as we posit the structure of historicity as an "ahistorical truth," however, we are still confronted with the same question: how is this truth conditioned by what is historical? Must we leave this question unanswered? - and if so, why? This was precisely Dilthey's (2010) concern when, after reading "Philosophy as a Rigorous Science," he observed that Husserl is able to interpret life only by abstracting from the "whole of life" (257). If the activity of historicizing experience is made dependent on a commitment to historicity as an ahistorical truth, then our ability to historicize experience would be made dependent on our willingness to uncritically stop as soon as we arrive at more "fundamental" levels of the life-world. Historicizing would have to give way to a kind of ahistoricizing.

Critical phenomenology's commitment to analyzing the socio-historical conditions of phenomenological description itself sets it in clear opposition to this Husserlian concept of historicizing. To historicize in this way would be to accept that the silent histories behind our ideas of "what historicity is" ought to remain silent, and to ignore Guenther's warning that " $[w]$ e overlook them at our peril." Consider Sara Ahmed's (2006) discussion of the phenomenological epoché in Queer Phenomenology. After observing that the phenomenologist brackets the life-world and attends to the essence of what is experienced, she emphasizes that the domestic world which is bracketed in this process continues to condition the phenomenological attitude:

What does it mean to assume that bracketing can "transcend" the familiar world of experience? Perhaps to bracket does not mean to transcend, even if we put something aside. We remain reliant on what we put in brackets . . . What is 'put aside,' we might say, is the very space of the familiar, which is also what clears the philosopher's table and allows him to do his work. (33-34).

In the phenomenological attitude, the phenomenologist continues to make use of language, the body, material things such as paper, a desk, etc.- all things which have a history. As Ahmed says, "[w]e remain reliant on what we put in brackets": we remain historically situated even when we bracket our own historicity. What is especially important in Ahmed's discussion here is the implication that we need to historicize beyond what phenomenology allows, i.e., to historicize even the phenomenological attitude. Ahmed asserts the need to investigate histories which condition the phenomenological attitude, and this includes

${ }^{18}$ Johnson (1980) makes the same claim as Carr in his own discussion of Husserl (87-88). 
histories which have shaped our experience of "gendered bodies." Once we recognize that the phenomenological epoché presupposes a masculine subject who is able to "disappear" from his situatedness and inhabit the phenomenological attitude, we are led to the possibility of a queer phenomenology: an analysis which would "turn the tables" on phenomenology and examine its own gendered conditions (63).

By suggesting the need to historicize whatever is said of historicity, critical phenomenology turns back on Dilthey and Husserl's disagreement and moves in the direction of Dilthey's interpretation of historicity. As we have seen, Dilthey believed that it is only through the activity of historicizing that we come to understand our historical situatedness. For Dilthey, there is no point at which understanding is permitted to separate itself from historicizing - to understand our historical situatedness we have to historicize understanding itself, and recognize that even our ideas about our historical situatedness are historical. Correspondingly, the activity of historicizing is something entirely different for Dilthey. While for Husserl our historical situatedness can be brought into view and interpretatively deconstructed (Abbau), for Dilthey our historical situatedness can never be brought entirely into view - our interpretation of it is necessarily a constructive activity (Aufbau) (Makkreel 1982, 55). Whatever our interpretation of history might be, this interpretation must always be re-opened through the activity of historicizing: we have to recognize that our sense for history is contingent, and then attempt to construct the history behind our sense of history by way of appeal to what is given in experience - e.g., the expressions of others, cultural systems, works of art, political movements, etc. This is why the activity of historicizing becomes for Dilthey a source of radical possibility. To historicize experience is to recognize the contingency of the way we experience things, and to open ourselves to the possibility of experiencing otherwise.

Here is where I think Dilthey - and reflection on the Dilthey-Husserl debate - has relevance for critical phenomenological research. Insofar as Dilthey approaches our historical situatedness as an object of historical interpretation, his analysis leads us to conceive of the activity of historicizing not as giving meaning to our experiential life, but as continually re-opening the question of the meaning of our experiential life in a way that allows for critical interrogation. Stated more simply, Dilthey's recognition that our historicity needs to be historicized itself moves toward the insight that subjects can be situated in history in vastly different ways, and historical interpretation is precisely what enables us to criticize conceptions of history which suppress this difference. While critical phenomenologists have made extensive use of historicizing, their commitment to examining the ways that power conditions the phenomenological attitude has largely led them to steer clear of the notion of "historicity." If we follow Dilthey's thinking about historicizing, however, it becomes possible to speak of the plural historicities, i.e., historically specific ways of relating to and becoming situated within history.

In Solitary Confinement, Guenther (2013) approaches this alternative way of thinking about historicity when she describes the reality of "social death." She explains that the socially dead (e.g., prisoners in solitary confinement) are persons who are "excluded, dominated, or humiliated to the point of becoming dead to the rest of society" (xx). Such people are removed from the network of intersubjective relations which alone makes possible 
personhood, but equally also from the relations which make possible a historical horizon. Guenther observes that socially dead persons become separated from both past and future generations, and therefore abandoned to an existence that is separated from a historical community. She asks: "Without a living relation to past and future generations, who am I? Do I still have a stake in historical time?" (xxiii).

As soon as Guenther's analysis brings her to the point of recognizing that intersubjectivity is fundamental to the possibility of historicity, she asks herself: is it possible to fall out of our situatedness within history? Is the character of historical existence itself dependent on our being positioned within a network of intersubjective relations? - and thus a privilege for some and not others? What is significant about this moment in Solitary Confinement is that Guenther draws on the histories of prisoners in solitary confinement in order to arrive at the suggestion that our historicity is something contingent. To be "historically situated" is to experience in a socially and historically privileged way, and if we attempt to interpret the history behind one's "historical situatedness," we will be brought before the possibility of experiencing otherwise.

If critical phenomenologists are to consider the silent histories behind our historical situatedness - and thus to speak of the plural historicities - they will need to take a hermeneutic approach to historicity. It is here that Dilthey's opposition to Husserl is informative for critical phenomenology. As we find in Dilthey's reevaluation of understanding, the condition of being historical does not need to be approached transcendentally - it can also be approached by way of historical interpretation. This is what is entailed by a radical concept of historicizing. Now in arguing for the advantages of a hermeneutic approach to historicity, my intention is not at all to represent Dilthey as a model for critical phenomenology. As I have mentioned, Dilthey's treatment of historicity has been as much a problem for hermeneutic thinking as it has been a solution. Heidegger and Gadamer, for instance, directed strong criticisms at Dilthey for his continued commitment to the possibility of objectively valid understanding. ${ }^{19}$ Despite asserting the historical situatedness of understanding, Dilthey's fear of lapsing into skepticism led him to assert that an understanding of what is given in experience can only be considered genuine if it remains valid outside of its own situatedness. Dilthey maintains that our historical situatedness is simultaneously that which makes possible understanding and that which limits understanding (Linge 1973, 544).

As a way of conclusion, however, I believe the insight in Dilthey's response to Husserl in 1911 - that it is possible to reconceive of understanding as an essentially historical activity can be read as the promise of a genuinely hermeneutic treatment of historicity. Such a reading would allow us to say that critical phenomenology belongs within the tradition that has worked to fulfill this promise. Heidegger (2009), for one, observed that Dilthey was the first to achieve "a truly radical awareness" of the problem of historicity, but that what remained to be further developed in his work was the ontological character of historicity (72).

${ }^{19}$ See, for instance, Heidegger (2008, 454-55, 2011); Gadamer (2013, 222-44). 
In Being and Time, Heidegger tells us that his project of a fundamental ontology of Dasein is an extension of Dilthey's hermeneutical project, but one which grasps that Dasein is historical in its being, and that even its historicity needs to be understood in terms of its factical Being-in-the-world (Heidegger 2008, 454-55). ${ }^{20}$ Gadamer's philosophical project has similarly emerged out of an engagement with Dilthey. Like Heidegger, Gadamer (2013) asserts that Dilthey's concept of historicity needs to extended beyond his commitment to the possibility of objectively valid understanding what is required is the acknowledgement that "[t]o be historically means that knowledge of oneself can never be complete" (313). ${ }^{21}$ Any understanding we might have of our historical situatedness is necessarily rooted in "prejudices," i.e., the "biases of our openness to the world," and thus remains to be taken as an object of historical understanding itself (Gadamer 2008, 9). ${ }^{22}$

Critical phenomenologists' efforts to re-problematize the relationship between phenomenology and history should be seen as an extension of this same line of hermeneutic thinking. Insofar as critical phenomenology is committed to analyzing what is historicallyspecific in phenomenology's focus on transcendental structures, historicity itself needs to be made an object for historical interpretation - and one finds precisely this effort in the tradition of philosophical hermeneutics since Dilthey. Perhaps this is what we discover in revisiting the Dilthey-Husserl debate, then: an opportunity for critical phenomenology to reconsider its historical roots.

\section{REFERENCES}

Ahmed, Sara. 2006. Queer Phenomenology: Orientations, Objects, Others. Durham, NC: Duke University Press.

Bambach, Charles. 2019. "Hermeneutics and Historicity: Dilthey's Critique of Historical Reason." In Interpreting Dilthey: Critical Essays, edited by Eric S. Nelson, 82-102. Cambridge: Cambridge University Press.

Biemel, Walter. 1968. "Der Briefwechsel Dilthey-Husserl." Man and World 1 (3): 428-46.

Burke, Megan. 2020. "Heteronormativity." In 50 Concepts for a Critical* Phenomenology, edited by Gail Weiss, Ann V. Murphy, \& Gayle Salamon, 161-68. Evanston, IL: Northwestern University Press.

\footnotetext{
${ }^{20}$ Of course, this is not to downplay the profound importance of Husserlian phenomenology for Being and Time. My intention is only to emphasize that Heidegger's hermeneutics of factical Dasein draws on Dilthey's treatment of historicity rather than Husserl's. For an extensive discussion of Heidegger's extension of Dilthey, the reader is encouraged to see Scharff(2018).

21 See also Gadamer (2008, 11).

${ }^{22}$ For an extended discussion of Gadamer's extension of Dilthey, see Linge (1973, 546-53).
} 
Carr, David. 1974. Phenomenology and the Problem of History: A Study of Husserl's

Transcendental Philosophy. Chicago: Northwestern University Press.

De Mul, Jos. 2014. The Tragedy of Finitude: Dilthey's Hermeneutics of Life. Translated by Tony Burrett. New Haven, CT: Yale University Press.

Dilthey, Wilhelm. 1960. Gesammelte Schriften VIII. Band, Stuttgart: B.G. Teubner Verlagsgesellschaft.

- 1977. Descriptive Psychology and Historical Understanding. Translated by

Richard M. Zaner and Kenneth L. Heiges. The Hague: Martinus Nijhoff.

1989. Selected Works I: Introduction to the Human Sciences, edited by Rudolf

A. Makkreel \& Frithjof Rodi. Princeton: Princeton University Press.

- 1990. Gesammelte Schriften IV. Band, besorgt von Karlfried Gründer \& Frithjof Rodi. Stuttgart: B.G. Teubner Verlagsgesellschaft.

- 2010. Selected Works III: The Formation of the Historical World in the

Human Sciences, edited by Rudolf A. Makkreel \& Frithjof Rodi. Princeton, NJ: Princeton University Press.

- 2018. Selected Works IV: Hermeneutics and the Study of History, edited by

Rudolf A. Makkreel \& Frithjof Rodi. Princeton, NJ: Princeton University Press.

—. 2019. Selected Works VI: Ethical and World-View Philosophy, edited by

Rudolf A. Makkreel \& Frithjof Rodi. Princeton, NJ: Princeton University Press.

Dilthey, Wilhelm \& Grafen Paul Yorck von Wartenburg. 2020. Briefwechsel zwischen Wilhelm Dilthey und dem Grafen Paul Yorckv. Wartenburg, 1877-1897, edited by Gräfin Sigrid von der Schulenburg. Middleton: BiblioLife Press.

Ermarth, Michael. 1978. Wilhelm Dilthey: The Critique of Historical Reason. Chicago: University of Chicago Press.

Forster, Michael N. 2019. "Dilthey's Importance for Hermeneutics.” In Interpreting Dilthey: Critical Essays, edited by Eric S. Nelson, 61-101. Cambridge: Cambridge University Press.

Gadamer, Hans-Georg. 2008. "The Science of the Life-World." In Philosophical Hermeneutics, edited and translated by David E. Linge, 182-97. Berkeley: University of California Press.

- 2008. "The Phenomenological Movement." In Philosophical Hermeneutics, edited and translated by David E. Linge, 130-81. Berkeley: University of California Press. 
_ 2013. Truth and Method. Translated by Joel Weinsheimer and Donald G. Marshall. London: Bloomsbury Academic.

Guenther, Lisa. 2013. Solitary Confinement: Social Death and its Afterlives. Minneapolis: University of Minnesota Press.

- 2020. "Critical Phenomenology." In 50 Concepts for a Critical* Phenomenology, edited by Gail Weiss, Ann V. Murphy, \& Gayle Salamon, 11-16. Evanston, IL: Northwestern University Press.

Heidegger, Martin. 2008. Being and Time. Translated by John Macquarrie and Edward Robinson. New York: Harper Perennial Modern Classics.

- 2011. The Concept of Time: The First Draft of "Being and Time." Translated by Ingo Farin. New York: Continuum.

Hertog, Francois \& Michael Werner. 2014. "History/Story." In Dictionary of Untranslatables: A Philosophical Lexicon, edited by Barbara Cassin, Emily Apter, Jacques Lezra, \& Michael Wood, 439-40. Princeton, NJ: Princeton University Press.

Husserl, Edmund. 1970. Crisis of the European Sciences and Transcendental Phenomenology, translated by David Carr. Chicago: Northwestern University Press.

- 1977. Phenomenological Psychology, translated by John Scanlon. The Hague: Martinus Nijhoff.

- 1983. Ideas Pertaining to a Pure Phenomenology and to a Phenomenological Philosophy: First Book. Translated by F. Kersten. The Hague: Martinus Nijhoff.

—. 1989. "Origin of Geometry." In Edmund Husserl's Origin of Geometry: An Introduction. Translated by David Carr, 155-80. Lincoln: University of Nebraska Press.

—. 2001. The Shorter Logical Investigations, translated by J. N. Findlay. London: Routledge.

—. 2002. "Philosophy as a Rigorous Science." In The New Yearbook for Phenomenology and Phenomenological Philosophy II, edited by Burt Hopkins and Steven Cromwell.

Translated by Marcus Brainard: 249-95.

Jalbert, John E. 1988. "Husserl's Position Between Dilthey and the Windelband-Rickert School of Neo-Kantianism." Journal of the History of Philosophy 26 (2): 279-96.

Johnson, Galen A. 1980. "Husserl and History." Journal of the British Society for Phenomenology 11 (1): 77-91. 
Linge, David E. 1973. "Dilthey and Gadamer: Two Theories of Historical Understanding." Journal of the American Academy of Religion 41 (4): 536-53.

Makkreel, Rudolf. A. 1982. "Husserl, Dilthey, and the Relation of the Life-World to History." Research in Phenomenology 12: 39-58.

Moran, Dermot. 2018. "Husserl's Hermeneutics: From Intuition of Lived Experiences to the Horizonal Lifeworld." In Hermeneutics and Phenomenology: Figures and Themes, edited by Saulius Geniusas \& Paul Fairfield, 122-43. London: Bloomsbury.

Noé, Keiichi. 1992. "The Hermeneutic Turn in Husserl's Phenomenology of Language." Human Studies 15 (1): 117-28.

Owensby, David. 1988. "Dilthey and Husserl on the Role of the Subject in History." Philosophy Today 32 (3): 221-31.

Rand, Calvin G. 1964. "Two Meanings of Historicism in the Writings of Dilthey, Troeltsch, and Meinecke." Journal of the History of Ideas 25 (4): 503-18.

Salamon, Gayle. 2018. "What's Critical about Critical Phenomenology?" Puncta: Fournal of Critical Phenomenology 1: 8-17.

Scharff, Robert C. 2018. Heidegger Becoming Phenomenological: Interpreting Husserl through Dilthey, 1916-1925. Lanham, MD: Rowman \& Littlefield Publishers.

Smith, David Woodruff. 2013. Husserl. Abingdon: Routledge.

Weiss, Gail and Andrew Cutrofello. 2019. "Introduction." The Journal of Speculative Philosophy 33 (3): 341-48.

Weiss, Gail, Ann V. Murphy, \& Gayle Salamon, ed. 2020. 50 Concepts for a Critical* Phenomenology. Evanston, IL: Northwestern University Press.

Yancy, George. 2020. "Confiscated Bodies." In 50 Concepts for a Critical* Phenomenology, edited by Gail Weiss, Ann V. Murphy, \& Gayle Salamon, 69-75. Evanston, IL: Northwestern University Press. 